FOLIA POMERANAE UNIVERSITATIS TECHNOLOGIAE STETINENSIS

Folia Pomer. Univ. Technol. Stetin., Oeconomica 2017, 335(87)2, 273-282

Mariusz SZAŁAŃSKI, Władysława ZBOROWSKA*

\title{
SYMULACJE MAKROEKONOMICZNE W EDUKACJI EKONOMICZNEJ PRZYSZKYCH MENEDŻERÓW. DOŚWIADCZENIA WYDZIAŁU ZARZĄDZANIA UNIWERSYTETU WARSZAWSKIEGO
}

\section{MACROECONOMY SIMULATIONS IN ECONOMIC OF FUTURE MANAGERS. FACULTY OF MANAGEMENT UNIVERSITY OF WARSAW EXPERIENCES}

\author{
Samodzielny Zakład Metod Matematycznych i Statystycznych, Uniwersytet Warszawski \\ ul. Szturmowa 1/3, 02-78 Warszawa, e-mail: mszalanski@wz.uw.edu.pl \\ *Katedra Gospodarki Narodowej, Uniwersytet Warszawski \\ ul. Szturmowa 1/3, 02-678 Warszawa, e-mail: wzborowska@wz.uw.edu.pl
}

\begin{abstract}
Summary. The models of national economy are one of the main tools of analysis makroeconomic. The article presents simulation macroeconomic models used in teaching economics future managers at Faculty of Management at the University of Warsaw. We present examples of the use simulation models and their importance in teaching macroeconomics from the point of view of students and lecturers.
\end{abstract}

Słowa kluczowe: dydaktyka, makroekonomia, modele ekonomiczne, symulacje, rynki, równowaga makroekonomiczna.

Key words: didactics, macroeconomics, macroeconomics models, simulations, markets, macroeconomic balance.

\section{WSTĘP}

Ekonomia stanowi ważny aspekt ogólnej edukacji przyszłych menedżerów. Światowy kryzys finansowy i jego skutki dla gospodarek narodowych uwidoczniły luki w nauczaniu ekonomii na studiach menedżerskich. Okazuje się jednak, że przykładowo w makroekonomii wystarczy wyposażyć studentów w odpowiedni zasób teoretycznej wiedzy, wykształcić umiejętność praktycznego posługiwania się tą wiedzą w interpretowaniu zjawisk i procesów zachodzących w gospodarce krajowej i światowej, a także nauczyć ich samodzielnego wyciągania wniosków w praktyce.

Efektywność edukacji ekonomicznej menedżerów wymaga połączenia solidnych podstaw teoretycznych z rozwijaniem umiejętności ich zastosowania w rozwiązywaniu rzeczywistych problemów gospodarczych. Takie podejście wymaga jednak zastosowania w znacznie szerszym zakresie nowoczesnych form nauczania ekonomii, które skłaniają studentów do samodzielnego analizowania i poznawania danego przedmiotu. Może to być m.in. studiowanie dodatkowej literatury, case studies oraz wprowadzenie do systemu nauczania symulacji komputerowych.

Połączenie wymienionych form w praktyce dydaktycznej stwarza podstawy właściwego przygotowania teoretycznego i wykształcenia umiejętności zastosowania w praktyce wiedzy ekonomicznej przez przyszłych menedżerów. Gwarantuje także wyrobienie nawyku uzupełniania 
i aktualizacji wiedzy ekonomicznej w całym okresie aktywności zawodowej. Dobrym przykładem zmian w edukacji ekonomicznej przyszłych menedżerów, w celu dostosowania ich do nowych wyzwań rzeczywistości gospodarczej, jest wdrażany od prawie 8 lat projekt dydaktyczny z zakresu makroekonomii na Wydziale Zarządzania Uniwersytetu Warszawskiego (WZ UW). Na wydziale makroekonomia jest wykładana na studiach licencjackich (stacjonarnych i niestacjonarnych) na kierunkach zarządzanie oraz finanse i rachunkowość. $\mathrm{Na}$ zarządzaniu makroekonomia jest realizowana na drugim roku, z podziałem na makroekonomię I oraz II. Przy czym makroekonomia I obejmuje kurs podstawowy z przedmiotu i jest prowadzona w formie wykładów oraz ćwiczeń (kurs kończy się egzaminem). Makroekonomia II jest natomiast prowadzona w formie konwersatorium; obejmuje problematykę zastosowania polityki makroekonomicznej w oddziaływaniu na gospodarkę (kończy się zaliczeniem na ocenę).

Celem nauczania makroekonomii na WZ UW jest zapoznanie studentów z podstawami teoretycznymi uwarunkowań i zależności w funkcjonowaniu gospodarki rynkowej, wyposażenie ich w adekwatne narzędzia analizy makroekonomicznej oraz wykształcenie umiejętności zastosowania tych narzędzi do oceny zmian zachodzących w gospodarce w dobie globalizacji i integracji.

Wyniki corocznych ankiet dydaktycznych, przeprowadzanych wśród studentów Wydziału Zarządzania UW, wskazują, że makroekonomia była postrzegana przez słuchaczy jako przedmiot trudny, a przez wielu - jako przedmiot abstrakcyjny. Przygotowując projekt dydaktyczny, przyjęto, że należy wprowadzić zmiany powodujące, iż makroekonomia stanie się dla przyszłych menedżerów przedmiotem fascynującym, który pozwoli im zrozumieć, z jakimi problemami w skali makro będą się stykać i jak będą mogli je skutecznie rozwiązywać. Kluczem do takiego rozumienia makroekonomii jest - zdaniem autorów artykułu - wprowadzenie nowoczesnych metod nauczania z zastosowaniem wspomagania komputerowego.

Celem artykułu jest prezentacja doświadczeń z stosowania symulacyjnych modeli makroekonomicznych w edukacji ekonomicznej przyszłych menedżerów.

\section{MATERIAŁ I METODY}

Przedstawienie w opracowaniu możliwości zastosowania wspomagania komputerowego w nauczaniu makroekonomii wymagało przestudiowania literatury z zakresu wykorzystywania modeli ekonomicznych w tym dziale ekonomii. W artykule odwołano się do treści zawartych w naszym podręczniku, pt. „Makroekonomiczne modele funkcjonowanie rynków w gospodarce. Symulacje komputerowe" (Zborowska i Szałański 2010), zawierającym charakterystykę funkcjonowania makroekonomicznych rynków w gospodarce z zastosowaniem modeli w wersjach: opisowych, algebraicznych i graficznych.

W podręczniku tym (Zborowska i Szałański 2010) zamieszczono autorskie metody symulacyjne służące wyjaśnieniu działania wybranych rynków w gospodarce, $z$ wykorzystaniem autorskiego programu komputerowego skonstruowanego na bazie arkuszy kalkulacyjnych programu Excel. W części wnioskowej opracowania są zaprezentowane obserwacje i wnioski, płynące z wieloletniego doświadczenia autorów artykułu, dotyczące realizacji wsparcia komputerowego makroekonomii na WZ UW. Wykorzystujemy także opinie studentów zawarte w corocznych ankietach oceny dydaktyki - dotyczące przydatności symulacyjnych modeli makroekonomicznych w przyswajaniu wiedzy i nabywaniu umiejętności jej stosowania w analizie makroekonomicznej. 


\section{OGÓLNA CHARAKERYSTYKA PROJEKTU DYDAKTYCZNEGO Z MAKROEKONOMII}

Głównym celem projektu było opracowanie i wdrożenie do nauczania makroekonomii nowoczesnego atrakcyjnego narzędzia, jakim są symulacje komputerowe. Wynika to z założenia, że obecni studenci są pokoleniem, które doskonale potrafi się poruszać w przestrzeni informatycznej. W związku z tym dostarczenie studentom nowoczesnego, a zarazem przyjaznego narzędzia, przyczyni się do lepszego zrozumienia przez nich skomplikowanych zależności makroekonomicznych, a wykładowcom pozwoli przedstawić je w przystępny i zrozumiały sposób.

Omawiany projekt dydaktyczny obejmuje dwie części. Pierwsza część zawiera skrypt oraz program komputerowy, dostosowane do realizowanych podstaw makroekonomii w ramach przedmiotu makroekonomia I; stanowi on uzupełnienie literatury podstawowej.

Skrypt zawiera podstawy funkcjonowania głównych rynków w gospodarce i determinanty równowagi krótkookresowej na tych rynkach. Do opisu funkcjonowania poszczególnych rynków zastosowano podejście popytowe zgodne z teorią makroekonomiczną J.M. Keynesa. Takie podejście jest bowiem wciąż użyteczne w objaśnianiu problemów współczesnej makroekonomii na poziomie podstawowym. Do charakterystyki poszczególnych rynków wystarczy prosta aparatura matematyczna w postaci funkcji liniowych wraz z ich interpretacją graficzną (Begg i in. 2014).

Układ skryptu jest tak skonstruowany, aby czytelnik mógł zapoznać się z analizowanymi problemami z teoretycznego i praktycznego punktu widzenia. Każdy bowiem rozdział opracowania zawiera podstawy teorii z zakresu omawianych zagadnień, rozwiązania przykładowych symulacji oraz zestawy symulacji do samodzielnego rozwiązania z zastosowaniem programu komputerowego.

Opracowanie składa się z 7 rozdziałów. W rozdziale pierwszym są charakteryzowane główne mierniki pomiaru aktywności gospodarczej, ich ujęcia nominalne i realne. Rozdział drugi zawiera analizę funkcjonowania rynku towarowego w gospodarce, z uwzględnieniem podejścia sektorowego - od modelu dwupodmiotowej gospodarki zamkniętej do modelu trójpodmiotowej gospodarki otwartej. W rozdziale trzecim opisano funkcjonowanie rynku pieniądza. Rozdział czwarty jest poświęcony działaniu makroekonomicznego rynku pracy. W rozdziale piątym omówiono równowagę makroekonomiczną w gospodarce zamkniętej z wykorzystaniem z modelu IS-M (Burda i Wyplosz 2013). Kolejny, szósty, rozdział dotyczy równowagi na rynku walutowym. Skrypt zamyka rozdział siódmy zawierający analizę równowagi makroekonomicznej w gospodarce otwartej z sektorem wymiany towarowej z zagranicą.

Taki układ problematyki przedmiotu pozwala studentom najpierw zapoznać się ze specyfiką funkcjonowania pojedynczych rynków w sposób wyizolowany. W dwóch ostatnich rozdziałach występują modele, dzięki którym łatwiejsze jest zrozumienie mechanizmów współdziałania rynków w warunkach gospodarki zamkniętej, a następnie - gospodarki otwartej.

Do skryptu dołączony jest program komputerowy, składający się z 7 modułów dostosowanych do zagadnień omawianych w poszczególnych rozdziałach. Program napisany jest w przyjaznym dla użytkowników oprogramowaniu Excel; jest dostępny na stronie internetowej Wydawnictwa Naukowego WZ UW.

Druga część projektu jest dostosowana do programu realizowanego w ramach przedmiotu makroekonomia II; dotyczy on zastosowania polityki makroekonomicznej do oddziaływania na gospodarkę. Także w tej części studenci mają do dyspozycji skrypt i odpowiedni program komputerowy. W skrypcie przedstawiono zastosowanie różnych wariantów polityki mieszanej 
do rozwiązywania określonych problemów makroekonomicznych. W warstwie metodologicznej wykorzystano makroekonomiczne modele równowagi krótkookresowej w odniesieniu do gospodarki zamkniętej i otwartej. Przedstawione modele pozwalają ocenić efektywność prowadzonej polityki makroekonomicznej i zrozumieć jej ograniczenia w warunkach zmieniającej się koniunktury w kraju i za granicą.

Przyjęta w obu skryptach formuła łączenia podstaw teorii makroekonomicznej z symulacjami komputerowymi umożliwia słuchaczom lepiej zrozumieć skomplikowane zależności ekonomiczne, a także pozwala weryfikować zastosowanie teorii w praktycznym rozwiązywaniu różnych problemów.

W naszym ciągu artykułu zostaną przedstawione doświadczenia z wdrażania pierwszej części omówionego projektu.

\section{PRZYŁADY ZASTOSOWANIA SYMULACJI KOMPUTEROWYCH DO ROZWIAZZYWANIA PROBLEMÓW MAKROEKONOMICZNYCH}

\section{Przykład I}

Przedstawia zastosowanie modelu symulacyjnego rynku towarowego w gospodarce zamkniętej, ale z udziałem państwa jako trzeciego podmiotu (model trójpodmiotowej gospodarki zamkniętej - Zborowska i Szałański (2010). Model ten pozwala studentom w prosty sposób zidentyfikować narzędzia oddziaływania państwa na globalny popyt w ramach realizowanej polityki fiskalnej oraz ocenić konsekwencje stosowanych rozwiązań.

W naszym przykładzie założono, że rząd zwiększa wydatki w następnym okresie (ryc. 1).

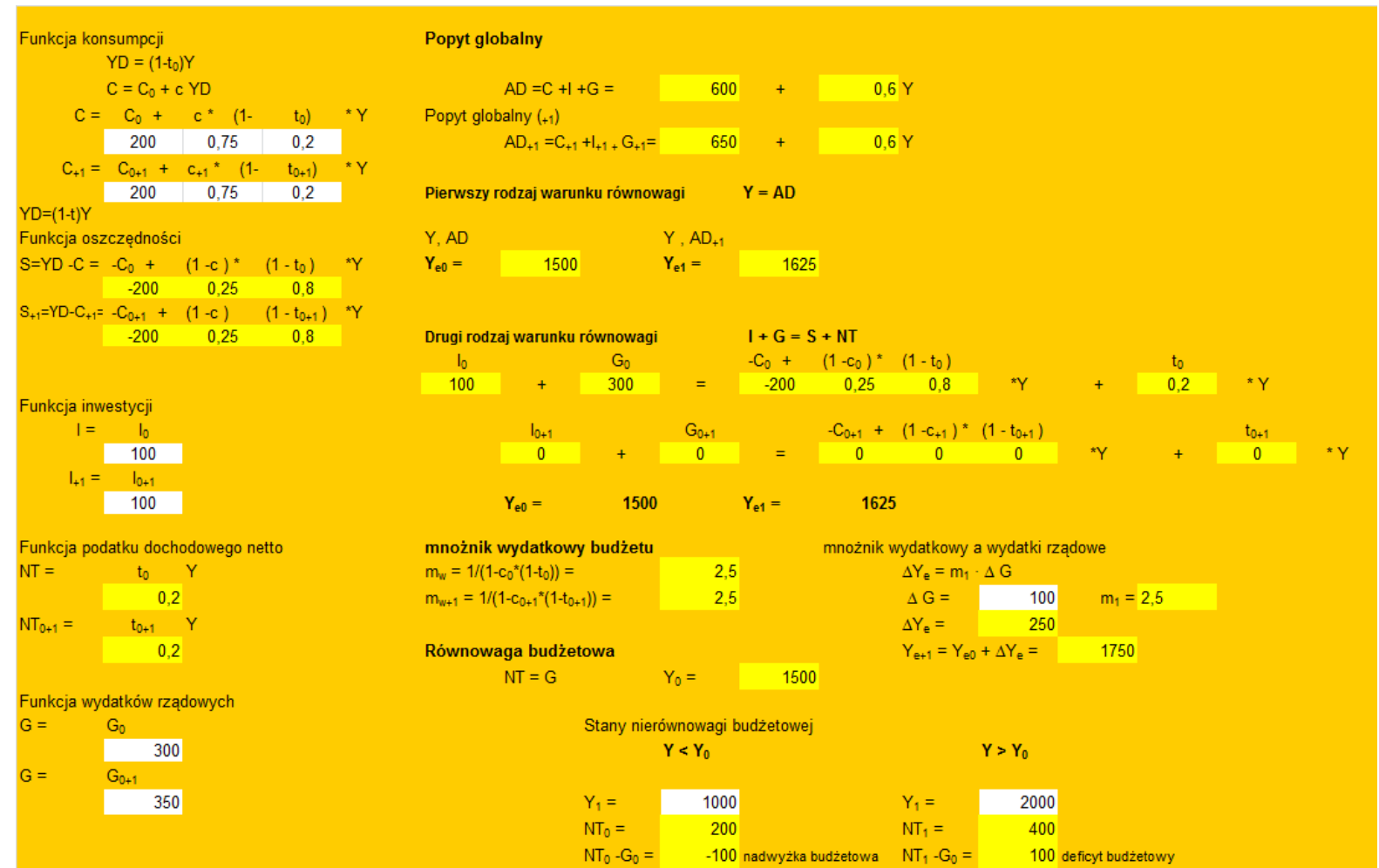

Ryc. 1. Program komputerowy MFR WZUW v.1 (fragment tablicy trzeciej - rynek towarowy w gospodarce trójpodmiotowej zamkniętej)

Źródło: opracowano na podstawie: Zborowska i Szałański (2009). 
Zwiększenie wydatków rządu o 50 jp. spowodowało, że wskutek wystąpienia efektów mnożnikowych produkcja i dochód równowagi wzrosły z 1500 jp. do $1625 \mathrm{jp}$. Model tego rynku pozwala ponadto ocenić stan budżetu dla danego okresu. W naszym przykładzie w roku wyjściowym budżet był zrównoważony, w okresie następnym, po uwzględnieniu zwiększonych wydatków państwa i utrzymaniu tej samej wysokości stopy podatku dochodowego netto, budżet wykazywał nadal deficyt. Wynika to ze zwiększonych wpływów do budżetu, naliczanych od wyższej podstawy (dochodu), które nadal były niższe od wzrostu wydatków budżetowych.

\section{Przykład II}

Ilustruje funkcjonowanie makroekonomicznego rynku pieniądza w krótkim okresie. Model ten pozwala ocenić wpływ zmian popytu i podaży pieniądza oraz ogólnego poziomu cen na stan równowagi na rynku pieniądza; może być zastosowany do oceny skutków zmian w polityce pieniężnej banku centralnego (sterowanie rozmiarami podaży pieniądza). Ten przykład przedstawia wpływ ekspansywnej polityki pieniężnej, realizowanej przez bank centralny, wyrażającej się zwiększeniem podaży pieniądza (ryc. 2).

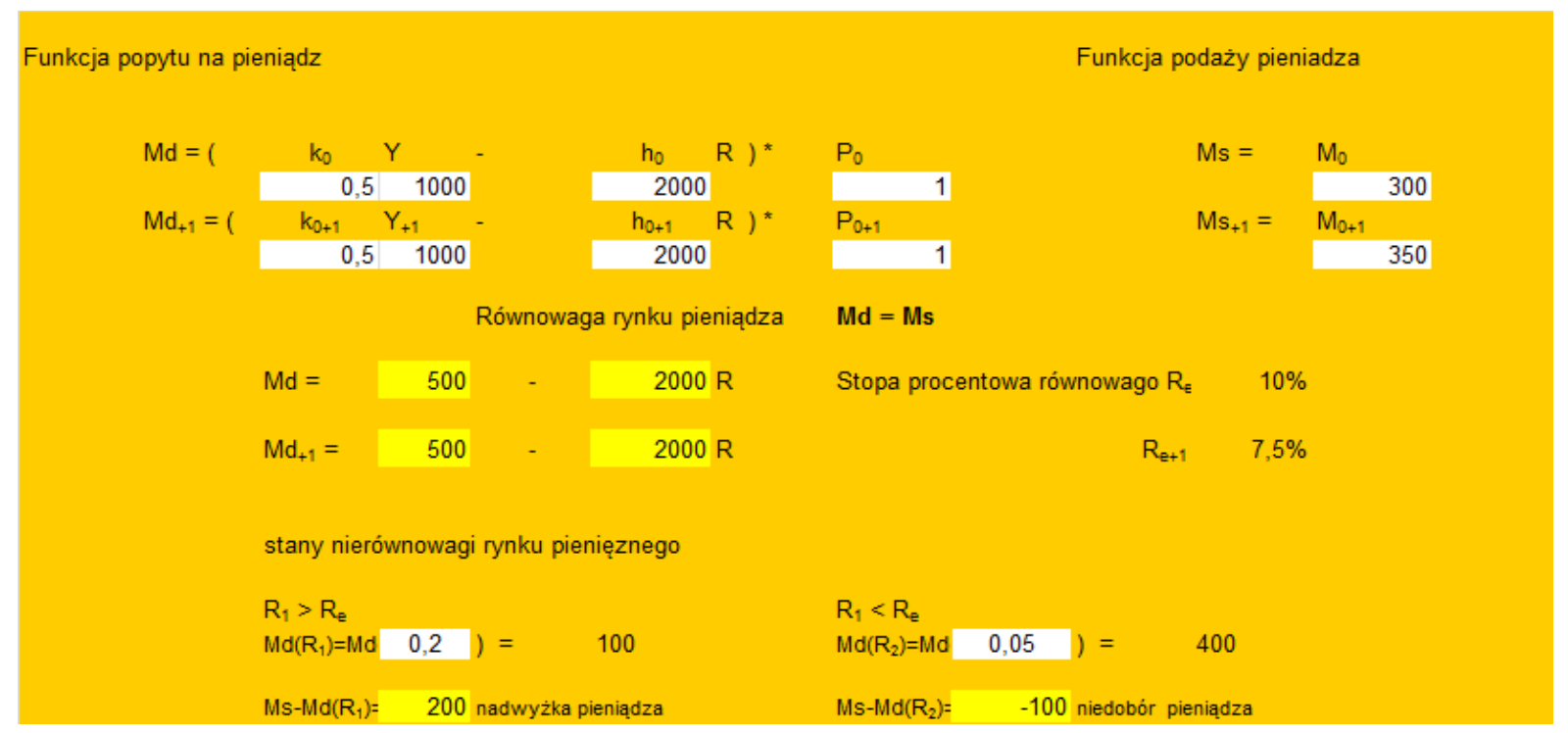

Ryc. 2. Program komputerowy MFR WZUW v 1.0 (fragment tablicy czwartej - rynek pieniądza) Źródło: opracowano na podstawie: Zborowska i Szałański (2009).

W następnym okresie bank centralny zwiększył podaż pieniądza, utrzymując stały popyt pieniądz oraz stały poziom cen $w$ gospodarce $w$ porównywanych okresach. W tych uwarunkowaniach obniżyła się stopa procentowa równowagi rynku pieniądza.

Przedstawioną zmianę model symulacyjny rynku pieniężnego pozwala zaprezentować także na wykresie, co ułatwia słuchaczom interpretację zależności między zmianą podaży pieniądza a stopą procentową, zapewniającą równowagę na tym rynku (ryc. 3). 


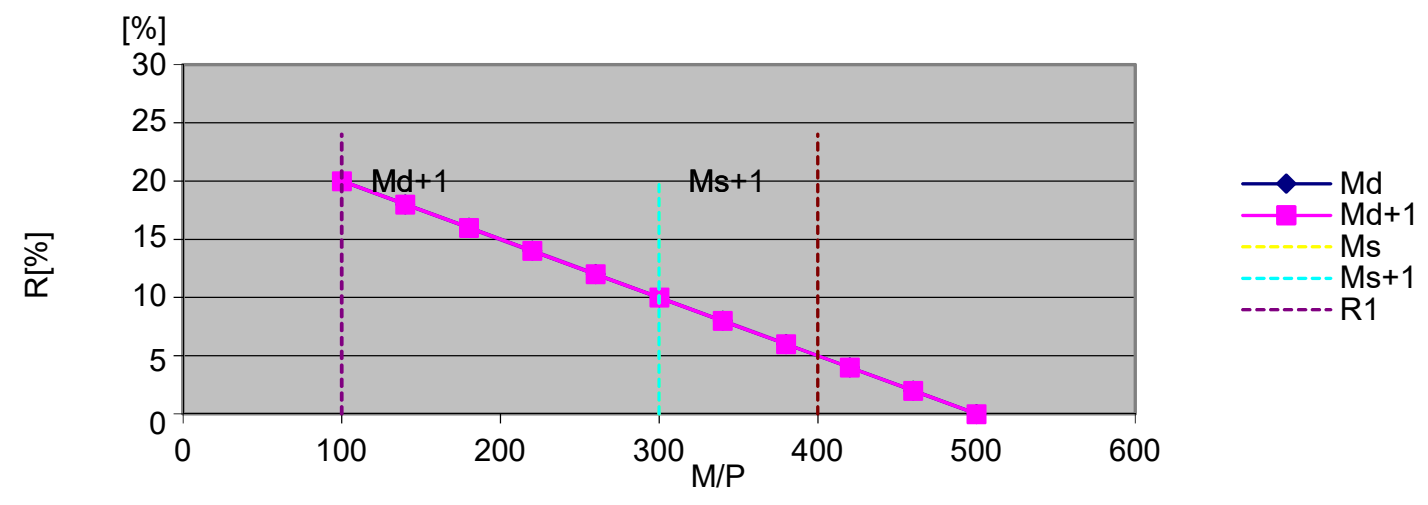

$\mathrm{M} / \mathrm{P}$ - realne zasoby pieniądza

$\mathrm{R}$ - stopa procentowa

Md $+1-$ popyt na pieniądz $w$ okresie +1

Ms +1 - podaż pieniądza w okresie +1

Ryc. 3. Punkty równowagi na rynku pieniądza

Źródło: opracowano na podstawie: Zborowska i Szałański (2009).

\section{Przykład III}

Dotyczy zastosowania modelu IS-LM pozwalającego obserwować współzależności między rynkami towarowym i pieniężnym w gospodarce zamkniętej. Pokazuje także konsekwencje stosowania różnych wariantów łączenia polityki fiskalnej i pieniężnej dla osiągania założonego celu, przy określonych uwarunkowaniach stanu gospodarki w okresie wyjściowym. Zakładając, że w następnym okresie celem polityki makroekonomicznej jest ożywienie gospodarki, czyli zwiększenie dochodu i produkcji, należy zastosować ekspansywną politykę fiskalną (wzrost wydatków rządu) oraz ekspansywną politykę pieniężną banku centralnego (zwiększenie podaży pieniądza) - ryc. 4.

W wyniku tych decyzji w gospodarce w następnym okresie popyt całkowity się zwiększył wzrosła wartość wszystkich składników popytu w tym modelu gospodarki. Ekspansywna polityka fiskalna spowodowała wzrost popytu, a ekspansywna polityka pieniężna banku centralnego, poprzez spadek stopy procentowej, stymulowała wzrost pozostałych składników popytu. Dlatego w następnym okresie produkcja i dochód równowagi odpowiednio się zwiększyły - wzrost gospodarczy osiągnął $4 \%$.

Ważną cechą modelu IS-LM w wersji komputerowej jest możliwość obserwowania innych skutków, wywołanych zastosowanym wariantem polityki mieszanej, a mianowicie obliczaniem poziomu całkowitej konsumpcji, całkowitych inwestycji i salda budżetu w warunkach równowagi w porównywanych okresach. Ta właściwość modelu pozwala także ocenić korzyści bądź straty poszczególnych grup podmiotów gospodarki narodowej w wyniku wdrożenia określonej kombinacji polityki fiskalnej i pieniężnej. 


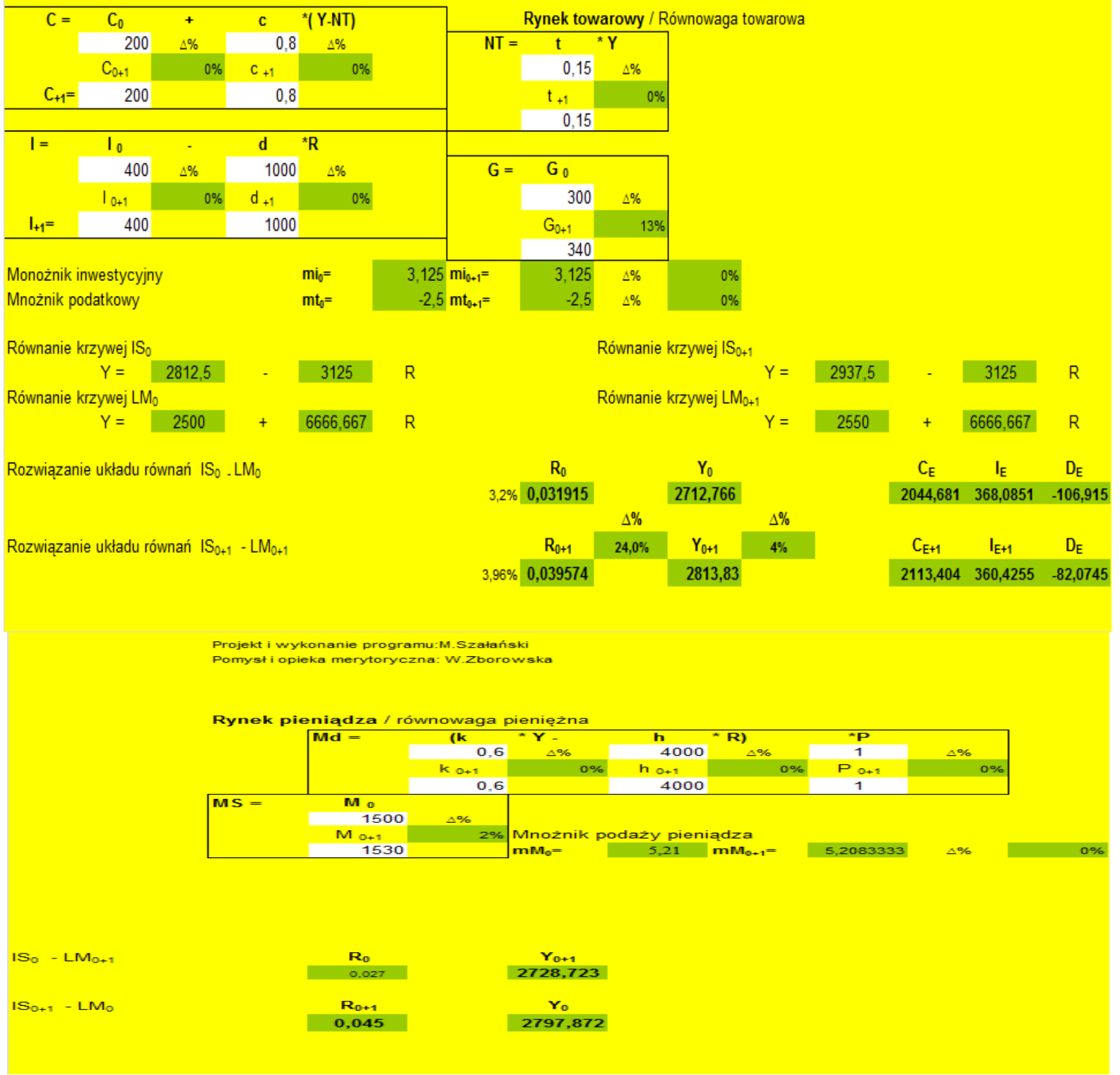

Ryc. 4. Program komputerowy IS-LM WZUW v 1.6 (fragment tablicy siódmej - IS-LM gospodarka zamknięta) Źródło: opracowano na podstawie: Zborowska i Szałański (2009).

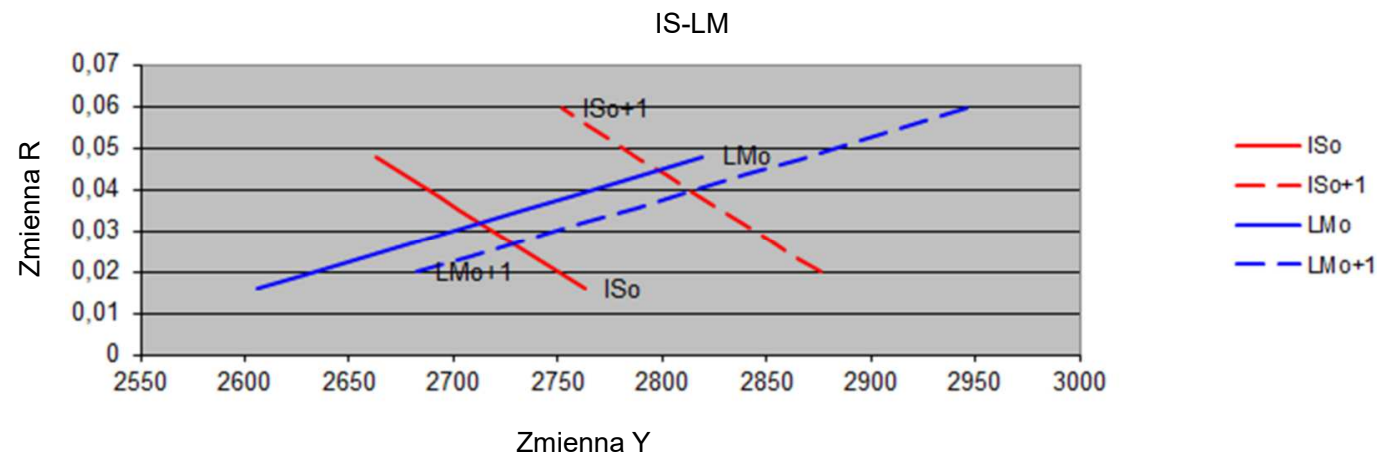

ISo - krzywa IS z okresu zerowego, ISo + 1 - krzywa IS z okresu + 1, LMo - krzywa LM z okresu wyjściowego LMo $+1-$ krzywa LM z okresu +1

Ryc. 5. Punkty równowagi makroekonomicznej w modelu IS-LM 


\section{KORZYŚCI Z ZASTOSOWANIA SYMULACJI KOMPUTEROWYCH W EDUKACJI MAKROEKONOMICZNEJ PRZYSZŁYCH MENEDŻERÓW}

Zastosowanie symulacji komputerowych w nauczaniu makroekonomii wpływa na zwiększenie aktywności studentów na zajęciach, ponieważ mogą oni pracować zarówno indywidualnie, jak i w grupach. Proponowana forma zajęć jest atrakcyjna dla słuchaczy - pozwala lepiej interpretować skomplikowane współzależności makroekonomiczne. Każde zadanie symulacyjne ma wyraźnie sprecyzowany cel, który powinien być osiągnięty przez zastosowanie odpowiedniego rozwiązania.

Makroekonomiczne modele symulacyjne, oparte na modelach popytowych równowagi krótkookresowej, mają wielki walor dydaktyczny, ponieważ stwarzają możliwość zastosowania podobnego podejścia przy objaśnianiu stosowania polityki makroekonomicznej w praktyce gospodarczej (Górski 2015).

Modele te zyskują także na aktualności w obliczu toczącej się dyskusji o znaczeniu roli państwa jako podmiotu polityki gospodarczej, zwłaszcza w sytuacji koniecznej interwencji rządów w łagodzeniu negatywnych skutków światowego kryzysu finansowego oraz w pobudzaniu przez nie gospodarki (Nowak i Ryć 2009).

Zastosowanie w nauczaniu makroekonomii modeli symulacyjnych zmusza do aktywnego uczestnictwa wszystkich słuchaczy i zdecydowanie tę aktywność zwiększa. Dzięki symulacjom studenci mogą w zrozumiały dla siebie sposób analizować wpływ konkretnych zmiennych na stan równowagi, oceniać siłę ich oddziaływania oraz identyfikować specyfikę oddzielnego działania na każdym opisywanym rynku.

Komputerowa wersja modelu IS-LM dla modelu gospodarki zamkniętej i otwartej, z sektorem wymiany towarowej z zagranicą, pomaga zrozumieć charakter współdziałania rynków, obserwować i oceniać skuteczność stosowania polityki fiskalnej oraz pieniężnej, wraz z ich ograniczeniami wewnętrznymi i zewnętrznymi. Dzięki symulacjom komputerowym wykładowca może przedstawić różne rozwiązania danego problemu, ze wskazaniem najlepszego wariantu.

W trakcie semestru studenci realizują ponadto co najmniej jeden projekt zespołowy, dotyczący zastosowania symulacyjnego modelu funkcjonowania rynków oraz polityki mieszanej. Przygotowując go, konsultują każdy etap z wykładowcami (bezpośrednio bądź drogą elektroniczną), zaś zakończony projekt przekazują wyłącznie e-mailem.

Dotychczasowe wieloletnie już doświadczenia WZ UW w realizacji omawianego projektu pozwalają stwierdzić, iż makroekonomiczne modele symulacyjne:

- służą lepszemu zrozumieniu specyfiki analizowanych rynków;

- kształtują u słuchaczy umiejętności interpretacji zmian zachodzących w makroekonomicznym otoczeniu biznesu;

- ułatwiają interpretację specyfiki działania polityki makroekonomicznej - uświadamiają jej możliwości i ograniczenia stosowania w gospodarce;

- pozwalają analizować skutki oddziaływania na gospodarkę szoków popytowych i podażowych (wewnętrznych i zewnętrznych) oraz sposoby redukowania ich negatywnych skutków;

- rozwijają umiejętności wykorzystywania informacji o sytuacji makroekonomicznej z punktu widzenia ich wpływu na szanse i zagrożenia dla firm; 
- umożliwiają realizację projektów zespołowych - wdrażają do pracy w grupie;

- stanowią dobre narzędzie utrwalania przez studentów nabytej wiedzy i jej zastosowania w rozwiązywaniu określonych problemów makroekonomicznych.

\section{PODSUMOWANIE}

Dotychczasowe doświadczenia stosowanego na WZ UW od prawie 6 lat dydaktycznego projektu upoważniają do stwierdzenia, że symulacyjne modele makroekonomiczne mogą być z powodzeniem wykorzystywane w nauczaniu makroekonomii na wszystkich poziomach studiów menedżerskich. Wyraźnie bowiem zwiększają zainteresowanie studentów makroekonomią. Symulacyjne modele makroekonomiczne są bardzo przyjaznym narzędziem, pozwalają łatwiej zrozumieć zawiłości makroekonomii oraz przełożyć wiedzę z tego przedmiotu na umiejętność identyfikacji zmian makro zachodzących w otoczeniu firm. Wydaje się, że wynika to $z$ faktu połączenia programu komputerowego z odpowiednio skorelowanym tematycznie skryptem. Narzędzia te pozwalają studentom na pracę indywidualną bądź zbiorową i są bardzo dobrym narzędziem do sprawdzenia i zastosowania w praktyce wiedzy teoretycznej z podstaw makroekonomii.

Mając świadomość pewnych niedoskonałości zaprezentowanego projektu, którego wdrożenie poprzedził pilotaż, wykorzystany do doskonalenia zarówno skryptów, jak i symulacji komputerowych, należy podkreślić, że projekt ten przyczyni się do zwiększenia wiedzy ekonomicznej przyszłych menedżerów. Sukces projektu na zajęciach z makroekonomii spowodował, że w Zakładzie Gospodarki Rynkowej Katedry Gospodarki Narodowej WZ UW podjęto prace nad wdrożeniem go także na zajęciach z mikroekonomii.

\section{PIŚMIENNICTWO}

Begg D., Vernasca G., Fischer S., Dornbusch R. 2014. Makroekonomia. Warszawa, PWE, 203-213. Burda M., Wyplosz Ch. 2013. Makroekonomia. Podręcznik europejski. Warszawa, PWE, 412-415.

Górski M. 2015. Makroekonomiczne skutki polityki fiskalnej i monetarnej w Polsce w latach 1992-2015, w: Gospodarka na rozdrożu XXI wieku. Warszawa, Wydaw. Nauk. WZ UW, 32-34.

Nowak A.Z., Ryć K. 2009. Jaki koniec kryzysu, w: Rynki finansowo-ubezpieczeniowe w warunkach kryzysu. Red. A.Z. Nowak, S. Nowak, A. Sopoćko. Warszawa, Wydaw. Nauk. WZ UW, 11-13.

Zborowska W., Szałański M. 2009. Program komputerowy MFR v.1.0. Warszawa, Wydaw. Nauk. WZ UW. Zborowska W., Szałański M. 2010. Makroekonomiczne modele funkcjonowania rynków w gospodarce. Symulacje komputerowe. Warszawa, Wydaw. Nauk. WZ UW, 29-33, 53-61. 
